\title{
The source of power of the Dayak Ma'anyan Tribes' political thought and its influence on the elites
}

\author{
Sumber kekuasaan dalam pemikiran politik Suku Dayak Ma'anyan dan \\ pengaruhnya terhadap elite
}

\author{
Kisno Hadi \\ Department of Government Studies, Faculty of Social and Political Sciences, \\ Universitas Kristen Palangka Raya \\ Address: Jalan J.P. Jandan No. 1, R.T.A. Milono KM 8.5, Sebangau, \\ Palangka Raya, Central Kalimantan 74874 \\ E-mail: kisnohadi@yahoo.co.id
}

\begin{abstract}
This article describes the political thoughts of power and authority, especially concerning sources of energy and its influences, in the elite group of the Dayak Ma'anyan tribe. Dayak Ma'anyan linked to the Nan Sarunai Kingdom, which was a sovereign country in the politic, economy, social and cultural scope in the 14th century. It collapsed because of the Majapahit military intervention. The elites' political thoughts highly influence the source of power in Nan Sarunai in the current era in local political practices. This article employed the descriptive, explanatory method paired with descriptive interpretative data analysis and enriched by in-depth interview to 10 informants. The analysed unit was an elite group of Dayak Ma'anyan in the Barito Timur Regency. The research discovered there to be two sources of power. First, there is procedure power, i.e. Adat (customary law), and second, there is substantial power, i.e. 1) Alatala (God) and Nanyu (gods or ancestry); 2) Tutur or Hurui (genealogy); 3) Panatau (treasuries) and 4) Pusaka Keagungan (symbols of power). These sources are the main influences of usable power, e.g. in the emerging of the East of Barito regency in 2002, in ethnic identity within the context of bureaucracy and elections. The data derived from in-depth interviews, Taliwakas (stories about local leader), Hiyang Wadian (sacred song of the priest in ritual), Sorosilah (stories on the histories of leaders) and the customary law of Dayak Ma'anyan. The data interpretation was based on the theory of traditional power by Benedict Anderson and the theory of the source of power by Charles F. Andrain.
\end{abstract}

Keywords: sources of power; political thought; influences; the elite

\begin{abstract}
Abstrak
Tulisan ini menggambarkan pemikiran politik suku Dayak Ma'anyan tentang sumber kekuasaan dan pengaruhnya terhadap elite masa kini. Suku Dayak Ma'anyan memiliki kronik kerajaan Nan Sarunai, negeri mereka yang berdaulat secara politik, ekonomi, sosial dan budaya di abad ke 14, dan mengalami kehancuran karena diserang militer Majapahit. Sumber-sumber kekuasaan di Nan Sarunai kini memengaruhi pemikiran politik elit dalam praktek politik lokal. Tulisan ini merupakan hasil penelitian menggunakan metode descriptive explanatory dengan analisis data deskriptif interpretatif, serta data wawancara dengan 10 orang informan. Unit analisisnya adalah elite suku Dayak Ma'anyan di Kabupaten Barito Timur, Kalimantan Tengah. Sumber kekuasaannya adalah: Pertama, prosedural yaitu Adat (Hukum Adat); dan Kedua, substansial yaitu 1) Alatala (Tuhan) dan Nanyu (dewa atau roh leluhur); 2) Tutur atau Hurui (genealogis); 3) Panatau (harta kekayaan material), dan 4) Pusaka Keagungan (simbol kekuasaan). Sumber kekuasaan tersebut memengaruhi praktek kekuasaan elite masa kini, yakni dengan pembentukan Kabupaten Barito Timur tahun 2002, politik identitas etnis di birokrasi dan dalam Pilkada. Tujuan penelitian ini ialah untuk menggambarkan pemikiran politik suku Dayak Ma'anyan tentang sumber kekuasaan dan pengaruhnya terhadap elit dalam politik lokal khususnya di Kabupaten Barito Timur di masa kini. Kesimpulannya ialah kekuatan kultural yang diwarisi dari pemikiran politik masa lalu, adanya kehendak kuat untuk mempertahankan adat dan budaya suku dan adanya kebijakan desentralisasi dan otonomi daerah yang memberi keleluasaan bagi masyarakat daerah melaksanakan pemerintahan berdasarkan adat dan budayanya, telah memberi ruang bagi masyarakat Dayak Ma'anyan mempraktekkan identitas budaya mereka dalam politik lokal. Interpretasi data menggunakan teori kekuasaan tradisional dari Benedict Anderson dan teori sumber kekuasaan dari Charles F. Andrain.
\end{abstract}

Kata kunci: sumber kekuasaan; pemikiran politik; pengaruh; elite 


\section{Introduction}

Dayak Ma'anyan is a tribe reside in Central Kalimantan with the number of population is about 2.8\% of total population (Suryadinata et al. 2003:26). Their life in the contemporary era are dense with tribunal vales and is highly associated with their history. They linked with the Nan Sarunai Kingdom, a sovereign kingdom in the 14th century, a centre of governance, human management, tradition, culture, and leadership. Back in the era, they recognised the concept of Mantir Epat Pangulu Isa as executor in tradition and governance aspect; and Miharaja as the supreme of government. Nan Sarunai collapsed because Javanese invasion (Majapahit) and the moment was known as "Sarunai Usak Jawa" (Java destroyed Sarunai) (Bae et al. 1995).

The era transformation could not fundamentally alter Dayak Ma'anyan people's collective perception of Nan Sarunai. The fall of the New Order regime in 1998 gives them plenty of room to romanticise Nan Sarunai. The post-New Order era is the moment to reaffirm their identity, which turns to be surprising and dilemmatic at once. It is surprising because decentralisation of politics and governance was first conceptualised for new bureaucracy efficiency as well as to bring democracy in the local governance level. The possibility of the communitarian rise never calculated, yet it becomes a vital part of decentralisation. On the other hand, it is dilemmatic because the problem of identity re-affirmation means the rise of the symbol of power before the establishment of the Republic of Indonesia, which represent feudalism (Klinken 2010:166).

Dayak Ma'anyan is a tribe who experienced the identity re-affirmation. They fought for the creation of Eastern Barito Regency until the area was established in 2002, which they refer as the extension of Nan Sarunai Kingdom (Ngepek 2008:1). Bureaucracy elites and Regional People's Representative Assembly (DPRD) as supported by traditional elites develop symbols of Nan Sarunai political power comprising the region symbol and the name of Building, Mantawara Building that was named after a cultural hall during Nan Sarunai era. In villages, the role of traditional leader still refer to Nan Sarunai legacy as the concept of Mantir Epat Pangulu Isa is still in practice. They seek and mystified local elite and grant them the status of traditional leaders hoping that the choosen figure could bring prosperity. The way Dayak Ma'anyan tribe live nowadays is highly influenced by the past political view, originated from the traditional way of life in the past.

One method to understood the concept of power is by obtaining the concrete form of authority within the context of history and social life. The advantages gained are: firstly, we could explain social custom, behaviour, and believe that historically related to the phenomena of authority. Second, we could redefine the past perspectives that influenced comprehension about authority in general. The description is related to authority gained from people in the previous era and the inheritance they left (Carter 1985:7). For Dayak Ma'anyan tribe, the original form of power on their sociohistorical context are derived from Nan Sarunai chronicles. In order to learn more in-depth about Dayak Ma'anyan thought, there is a need to observe any aspects related to their culture and tradition that frequently appears in the myth (Ukur 1974:4). Many believe that myth is not following rational thinking, unrealistic, but in myth, people can often find hidden facts (Borneo Institut 2013:10).

The Javanese political culture mainly dominates the political realm in Indonesia. In local Indonesian culture, long before modern perspective invented, people have recognised political thought derived from the social structure of the community within a region. In the past, the theory about politics and state has not yet explicitly mentioned. Instead, it incorporated with people's livelihood in general, especially belief and religion (Noer 1983:109-110).

In Katapang, Western Kalimantan, the practice of political authority in Dayak people is apparent on the role of informal leaders such as ethnic figure, head of the tribe, and public figure in preventing ethnic conflict (Asmu'ie 2006). Identity creation of Dayak tribe is known as a dialectical process between Dayak people as the main actor and their effort to construct and re-construct their identity. They further modify their identity as a response to market demand in the tourism industry. To achieve 
their objectives, Dayak tribe create an organisation whose primary purpose is to build cooperation such as Kenyah Customary Institution, consists of Head of Tribe and Head of Village (Maunati 2005:344-367). The fact illustrates the importance of the role of informal leaders in the local authority that originated from political thought in the past.

In Dayak Ma'anyan political thought, elites' role in managing authority is significant, especially in a self-organisation that was conducted collectively to achieve common objectives. Political authority in Dayak Ma'anyan political thought does not accurately administer governance issues, but also covering customary law (legislation) and belief. The myth of Nan Sarunai romanticise through the establishment of Eastern Barito regency, and the development of its public facilities illustrates how the tribe interpret their view of the traditional source of power in the past.

The question arises: how was the source of power in Dayak Ma'anyan political thought described? What is the influence of traditional authority on the elites in the current government? This article originated from a chapter in the authors' dissertation of Political Science in Universitas Indonesia. The research aims to reveal and to describe Daya Ma'anyan political thought about the source of authority toward local political elites, especially in Eastern Barito. Sources of authority are listed as follows: 1) Alatala (God) and Nanyu (gods or ancestry); 2) Tutur or Hurui (genealogy); 3) Panatau (treasuries), and 4) Pusaka Keagungan (symbols of power). The source of power classified as the traditional form of authority that influences the practice of current administration, conceptualised in the creation of Barito Timur regency in 2002 which regarded as the extension of Nan Sarunai, the practice of politics of identity in bureaucracy and the regional head election.

\section{Research Method}

This research employs a descriptive, explanatory research method. The descriptive research method will answer the question of "what" while analytical research method will address the problem of "why" and "how". Data analyzed through the qualitative interpretative method by highlighting social reality. The theory produced will be based on solid reality contextually and historically (Somantri 2005:64). This research conducted from April 2014 until March 2017 in the analysis unit area, Eastern Barito regency where Dayak Ma'anyan tribes reside. Elites analyzed in this research were cultural villages in Paju Epat and elites group in an urban area which classified as Tutur Mantir (leaders) as member of the urban middle-class association named Dusmala. Data utilized in this research is secondary data from relevant scientific research, local history script in written or oral form, and primary data by conducting observation and in-depth interview. There are ten informants confirmed on the research, i.g. KMA. M Usop and Arianto Muler (politics elite), Karno Dandan, Kasmody Leiyen, and Allen Ngepek (local community leaders), also Rodek Udir, Bhaterius B, Amah Gewung, Dalios, and Kurbel Suban (Adats Leaders of Dayak Ma'anyan).

\section{Result and Discussion}

Data analysis based on Javanese traditional political thought, as written by Ben Anderson about traditional authority and Andrain about sources of power. As mentioned by Weber, Anderson stated that traditional authority (Java) is the conceptualization of real power, even though it could not be touched, but the reality is concrete and full of mystery. It appears as a holistic point of view and provides life to the universe, taking form in every aspect of livelihood happens in the world, exists in every generation, which also regenerates. Javanese culture believes in political theory that provides a systematic and logical explanation about new political behaviour, and in many aspects, it is fundamentally contrary to the thought itself (Anderson 1984:52).

Andrain concept about the source of power stated that: First, authority gained from primordial sources such as offspring from a well-known family where only particular people have the authority to be a leader in a region. Second, leader acquires power from sources that deemed as holy, such as from God. Third, authority originated from private sources such as wealth, generosity, religious 
figure, and public figure. Fourth, authority obtained from instrumental sources such as achievements, experiences, and a high level of education. Fifth, in a constitutional state, authority is acknowledged from a legal basis, according to the procedures and regulation (Andrain 1992:194-197).

According to Surbakti, four sources of power, as mentioned by Andrain are classified as substantial sources of power, namely the right to rule based on inherent factors in the leaders such as tradition and personal quality. In addition, another source of authority is legislation, whether it occurs in natural and illiteral forms (Surbakti 1992:85-88).Referring to Andrain and Surbakti, sources of power in Dayak 'Ma'anyan political thought could be identified as procedural and substantial sources. Procedural sources are legislation, written and non-written (customary law). Substantial forms are identified as 1) Alatala (God) and Nanyu (gods or ancestry); 2) Tutur or Hurui (genealogy); 3) Panatau (treasuries), and 4) Pusaka Keagungan (symbols of power).

The source of power can be traced from the oral stories such as Taliwekas (the story about leadership), customary law, Hiyang Wadian (sacred singing from Tribe leaders performed in the traditional ceremony), and Sorosilah (history of leaders origin). The oral story identified by Hudson as traditional history (Hudson 1971:16), Dayak Ma'anyan tribe does not have letters for old script or inscription. Their history was spread through words and storytelling from generation through generation. Their source of power is highly associated with the belief system, custom, social system, including the myth of Nan Sarunai.

Nan Sarunai kingdom and the leaders can be traced as follows: 1) Tumpuk Laliku Meah (before 1305). The centre of governance located in Hujung Panti, close to Pangambangan, Southern Kalimantan. The leader was Pangulu Nini Punyut; 2) Kingdom of Nan Sarunai (305-1358) with the centre was in Kayu Tangi, near Martapura, Southern Kalimantan. The most well-known leader was King Anyan; 3) Bangi Sampa Tulen (1358-1389) with the heart of administration was located in the northern part of Tamian Layang, Eastern Barito, Central Kalimantan. One of the most prominent leaders was Uria Gadung; 5) Lasi Muda (1535-1850) with the centre in Dayu, Eastern Barito. A famous leader from the era was Uria Biring; 6) Landschaap Sihong (1850-1942) with the centre of administration was in Telang, Eastern Barito. The famous political leader was Suta Ono.

In the Dayak 'Ma'anyan political thought, started from the era before Nan Sarunai to the present, all customary rules and governance were designed verbally (unwritten), based on the memories and oral stories from leaders. Customary leadership and governance are managed and led by the concept of leadership of Mantir Epat Pangulu Isa. The tribal leader also plays the role of a customary leader who rules one of the leadership concepts of Mantir Epat Pengulu Isa. In the tribal leadership circle, the tribe always forms a power circle of five leaders called Mantir Epat Pangulu Isa, consisting of Pangulu (customary head), Pamakal (village government head), and three people called Mantir. The main task of Mantir is to help the customary head, and the head of the village administration manage everything related to adat and tribal governance which is carried out in groups consists of the three people. Tribal and customary leaders are a person with a sharp memory and can translate the rules in order to make people understand it easily. If leaders misremember the rules, it is the job of the Mantir to remind the leaders. For this reason, all three Mantir together with Pangulu (head of customary) and Pamakal (head of governance) should formulate and decide customary management and public administration.

The leader is chosen, determined and appointed from the descendants of the previous leaders. 'Tu'eh Tumpuk (elderly in the tribe) plays an essential role in electing leaders for the people, considering the voice of the public or leaders' family members point of view. The role of leaders does not always have to be handed down to children. It can be given to grandchildren, great-grandchildren, siblings, uncles, nephews, aunts, and also wives. The one who receives the role as leaders should belong to the group of Tutur Mantir, whether they are adult men or women.

To be a leader, one must fulfil the criteria as the notable comprehension toward customary rules, ability to lead the traditional ceremony and to manage the tribal government, descendants of Tutur 
'Mantir's family, having proper public speaking skills and open for guests and external cooperation for partnership. The ruler or tribal leader is also the leader of the tribal ritual, the decision-maker of the criminal case or act as a judge of traditional justice. They possess the right to extradite tribal people to be banished from the tribe from doing unforgivable manner.

In the Dutch colonial era, the head of government also became the head of the custom. Therefore, he had the right to decide a case and become a judge of the traditional justice system, and then he was entitled to receive 5\% money (wang bitjara) from the amount of fine imposed on the perpetrator who decided to be guilty as his salary. After Indonesia's independence, the role of the tribal chief as head of government with the area of coverage was equal to one regency, began to be cut down and reduced. Their authority was merely to be a customary head with only one or two sub-districts to administer. The titles of tribal chiefs were erased as people start to recognize the name into one title, namely Damang Adat. This tribal and customary leadership system still exists today, and its sources of power still influence the elites' thinking nowadays.

\section{Source of procedural power: Customary Law}

Tradition practised daily by a group of people manifested on customary law. However, the concept of custom is much more extensive than the customary law itself. In general, custom could be defined as behaviour related to law, tradition, habit, religious rites, and tribe leadership management. Every aspect related to Dayak people way of life categorized as custom (adat) or hadat (Tulus 2010:153). J.E. Garang urged the importance of custom in the Dayak social system, including in electing leader (Garang 1974, Miter 2017:9).

Custom categorised into two aspects: custom to regulate the way of life (hadat arrives welum) and customs for the ceremony of death (hadat arrives matei). The manifestations of these two concepts summarized in Dayak Ma'anyan tribe life philosophy, namely Welum Bahadat (living the life based on customs) (Maan Wada 2003:9). The concept of adat is manifested in customary law which rules about the rights and obligation of people in the community. There are 24 rules under Dayak Ma'anyan customary law for regulating people way of life and 19 types of rules for the ceremony of death. Two rules specifically mention about power, namely: 1) Dudus, is the process of inauguration or confirmation of the leader carried out by Mantir or Wadian (tribal priest). Within the process, the chosen leaders also officially given the title as the chief. Dudus can also be performed by leaders who are not classified as Mantir or Putak Amau. In completing the process, there are additional rituals known as Nindrik Langka, aims to eliminate destruction for ceremony holder in completing their duties; and 2) Kawit Kinte, is a process where one learns about leadership and customs, including customary law. Adolescence in the leader's family is the one obliged to learn about customary law, public speaking, expressing opinions in public, customs and its history, procedures for leading customary deliberations. They learned the abovementioned things to experienced tribal leaders (Mantir, chieftain, chief) as well as for Wadian (tribal leaders) (Gentong \& Dusau 2004:105-187).

Every Dayak Ma'anyan man, either the ruling elite or the people, should have always behaved based on an attached rule according to the fundamental belief of Dayak People. The reason behind this act is maintain the order of the universe to ensure that the world runs in the state of harmony and balance. Harmony and balance in Dayak Ma'anyan cosmic system are called as adat, consists of two fundamental views, namely: 1) order and harmony; and 2) life and actions following order and harmony (Ukur 1971:62). Adat should be portrayed broader than merely a set of rules, customs, methods, and ethics. The discussion about Adat encompasses a comprehensive narrative, not only between humans but involved events, all creatures and the universe, relations between humans, relations between human and other creatures and nature. In the context of Adat, traditional Dayak leaders are the primary executor of living arrangements based on prevailing customs. Even though customary rules have never been in the issued in written documents, they continue to apply such practices. Adat has rooted in tribal people way of life since they are bound by their religious consciousness (Measure 1971:63-64). 
In implementing custom rituals, tribal leaders carry essential roles. There are two leadership structures to administering the practice, which regulated by the Customary Council. These Indigenous Councils consist of two categories, namely: 1) Dewan Adat Tumpuk (Kampung). This structure is led by Pamakal (village head) whose members are known as tu'eh tumpuk (the elderly in the village) called Mantir. They have been involved in Dayak Ma'anyan traditional governance system since the era of Nan Sarunai, known as Mantir Epat Pangulu Isa (Four Mantir and One Pangulu people). This group have the authority to administer each ethnic group in Dayak Ma'anyan tribal government in; and 2) Regional level Customary Councils. A well-known leader of his area leads this Customary Council. Before the arrival of the Dutch colonial government, influential tribal chiefs who led Regional Indigenous Council held the title of Tamanggung or Dambung. After Dutch colonial came to power, the title was removed and replaced with Damang, who held the responsibility to regulate subdistrict, covering all villages within the subdistrict's territory. The members of the Customary Council are all Pangulu and Mantir in the villages within the governed area (Measure 1971:64-65).

In Dayak Ma'anyan political thought, the role of adat is essential in determining the life of tribal governance pattern, because acts, divine law, ritual rules are all included in the law that govern the lives of individuals, relatives and the whole tribal community (Measure 1971:65). Given the context, all rules of life, leadership, people, are covered in adat. Adat is relevant as a source of power in managing various aspect of Dayak Ma'anyan tribal life.

\section{Source of substantial power: Nanyu (God and ancestors)}

As mentioned by Miriam Budiarjo, beliefs or religion can be one of the sources of power (Budiardjo 2008:62). In the political thought of the Dayak Ma'anyan, long before they recognize the Indonesian Government acknowledged, Dayak Ma' anyan people had had their own belief. They believe that the world and the universe are controlled by the Gods and spirits of their ancestors. The ancestral spirit they trusted known as Nanyu. They also believe that leaders that exist today, such as tribal chiefs and customary leaders are descended from Gods (Agun 2016:5). Their leader before the Nan Sarunai era, Nini Punyut, was the son of a God, namely the son of Sawalang Gantung (the God of heaven) and Ungkup Batu (God of authority on earth). The heir of Nini Punyut became king of Nan Sarunai and inherited offspring to the Mantir, untill the present day. Nanyu was believed to have power over the lives of the Dayak Ma'anyan people and considered as equal to the Gods and act as the supernatural ruler. Nanyu, the spirit of leading figure ancestor from the past was believed as the one who takes care of their descendants and the place where the leader had lived and ruled.

Nanyu is a holy soul of Dayak Ma'anyan ancestors, a knowledgeable spirit that had turned into Gods. Therefore, its spirit had lifted and purified in a traditional death ceremony. Another precondition for the leader to be a Nanyu after their passing was the figure originated from the family of Tribal leaders and aristocrats. In addition, a prospective Nanyu should behave in the best possible way during their life and accomplished many good deeds for people (Bae et al. 1995:111). A story told by Mallinckrodt about Nanyu that guarded the life of Dayak Ma'anyan Paju Epat, particularly family of the tribal leaders, Suta Ono:

"Suta Ono was an extremely popular Chief of Dayak Ma'anyan tribe. One day, he travelled with the Dutch to Motallat. One night when he slept, in his dream, he met two women who introduced themselves as Nanyu Bukit Nandrueh. They stayed for the whole night with him and advised him to asked for help if something hazardous happened, and to always provided offerings. Suta Ono came to power and ruled wisely because he had a guard and protector in the family. He became the hero of Ma'anyan people; he was loved and highly adored. It has become clear how a personal protector, an ancestor become the spirit of a family, then escalated to be Gods of the tribe. Duties of deities started to become visible, to provide joy and prosperity." (Mallinckrodt 1974:13)

Mallinckrodt confirmed the existence of a guardian spirit, the holy virtue that becomes the source of power in Dayak Ma'anyan political thought. For Dayak Ma'anyan Paju Empat, a missionary named Tromp revealed Dayak Ma'anyan people belief in Sihong, an area ruled by Suta Ono: 
“Olon Ma'anjan (People of Ma'anyan) believe in Nanju (Nanyu), Saniang, and Diwata. Diwata is the God of water and Nanyu is the God of lightning. Suta Ono also had a Nanyu called Pangintoho, as long as I can recall, only belong to Suta Ono in Sihong and Ineh Gobo in Muruwutu. Pangintuhu that belongs to Suta Ono was the skull of his grandfather -Mangko Djaja- when his dead body burned, he did not turn into ash. He turned into coal, instead. Pengintoho was believed to be their protector and shielded them from Kelewang (European sword), spear, and bullet. As long as Pengintoho provided by offerings, they will stay in your back to protect you. Pengintoho is the Nanyu of the family, and Nanyu Pangintoho was the greatest one, so it was not supposed to be visible for everyone..." (Tromp 1878, Miter 2017:31).

The statement confirmed that in Dayak Ma'anyan political thought, Nanyu had become one source of power. It is relevant to Dubut's view about a message from ancestors, "If one day you happened to be in a critical condition and could no longer fight against the enemy, just call our name" (Dubut 2004:46). Calling ancestors name was a tradition advised by the ascendant when their descendant face problem and danger. Therefore, it has become clear that Nanyu is one source of power utilized to support and to boost confidence and power, especially for their offsprings who lead the tribe.

\section{Alatala (God)}

God noted as a source of power taking form in belief or religion (Budiarjo 2008:62). Source of supernatural power in Dayak Ma'anyan political thought was not only originated from Nanyu, but also form God. Before acknowledged-religion in Indonesia came, Dayak Ma'anyan people have recognised the existence of superior who rules the universe, and they named it as God or The Creator. According to Ukur, there are two approaches to God for Dayak Ma'anyan people. First: It was the eldest named as follows: "Datu Tantanyu; Maharaja Kulung Rakun; Datu Kumaking Langit; Raja Kiri Lalan Anrau; Raja Tantangan Langit; Ile Tungka Kahiangan". Name of youngest Gods listed as follows: "Tuhan Nguasa; Alahtala Ngaburiat; Tala Mana; Tuah Ukat". The names of God, as Ukur added, known as Alahtala was influenced by Islam, as it could not be found in hiyangan (singing) Suci Wadian. It was also not mentioned in the story about the world and humankind. The naming of God and Alahtala is simplified for Dayak Ma'anyan people until present (Ukur 1974:45-46).

Dayak Ma'anyan introduction to the concept of God was relatively new and influenced by the thought of other religion such as Islam and Christian. Before that, they believe in their belief system, which many perceived as a complicated one. Dayak Ma'anyan tribe believe in the existence of The Creator or Ilah that they described as the creator of the first human, which they refer as Hyang Piumung Jaya Pikuluwi (Miter 2015:13). However, according to Mallinckrodt, every household in Dayak Ma'anyan people have their protectors.

"Ma'anyan people have their own protectors, Nanyu, that was their ancestors at first but eventually became a supernatural creature. The ancestor was a personal guardian, they maintained a holy creature within the family and as a method to adore hero until God, and God is The Giver of joy and prosperity" (Mallinckrodt 2015:13).

In Dayak Ma'anyan political concept, God was not the sole ruler of this universe. There is a lower structure that belongs to the spirit of ancestors, a source of power for a particular family. They believe that the universe originated from The Creator, and human was first to exist as God's creation. God is deemed as a much higher power than the concept of Nanyu and Deieties. In this context, how God placed as a dominant source of power is relevant to the study conducted by Suseno about religious legitimacy. The right to rule belongs to the superior; it was not only adjusted to people's willingness or elites empirical leadership. Firstly, elites were perceived as an entity with supernatural power; thus they were no longer human, and their authority has become incontestable; and second, elites legitimacy to rule was based on Allah's (God's) provision (Suseno 2003:55-56).

The influence of God in Dayak Ma'anyan political thought was institutionalized into their adat rules and customary law they practised daily. In this point, God's authority influences every aspect of tribal life, behaviour, tradition, and mechanism to exercise power. 


\section{Panatau (Material wealth)}

Another source of power in the political thought of the Dayak Ma'anyan tribe is material wealth, as mentioned by Miriam Budiardjo that power could be originated from material wealth (Budiardho 2008:62). Possessing a lot of valuable goods and properties such as jars, gongs, pots, large estates and farmlands, a large longhouse, is a treasure that displays the prestige of a ruler in the tradition of Dayak Ma'anyan tribe. Ukur stated that there are at least seven generally known main characteristics of Dayak culture, namely: 1) Longhouses; 2) Mandau and Sumpitan; 3) Matting; 4) Pottery; 5) Farming System; 6) Dance; and 7) Position of Women in Society (Ukur 1992: 6-10). The first five main features are manifestations of material wealth. By owning it, especially in large quantities, a person will traditionally be honoured as the elites, the wealthy group, the ruler, and the influential aristocrats in society.

In the past, according to Ugang, wealth (panatau) was an important symbol of power. A considerable amount of wealth represents a person's influence in society. Ranying Suling, a Ngaju Dayak chief in Kahayan Hulu, is called as a "famous person" because he possessed three Balanga, 60 gongs, lived in a Betang House of 150 fathoms long, eight fathoms wide and four fathoms high from the ground. Fathom size is a type of traditional Dayak measuring instrument, where one fathom is the size of a width of the left hand and right hand of an adult male. Another figure widely known for his wealth was Keep Asang who has six Balanga, 30 gongs weighing 10-15 a half-carried, and 30 taels of gold was called "very famous among people in his era". While Damang Batu owned 23 Balanga, 40-50 Halamung, 400-500 Lalang, 200-300 gongs, 100 gold taels (approximately 2,000 kiping) was titled as "the most influential in the area at his time". Damang Batu hosted the Dayak Tribe Head's Peace Meeting in Tumbang Anoi (May 22-July 24, 1894) (Ugang 1987:64-66).

Meanwhile, Suta Ono who was the tribal leader in Telang (East Barito) (1850-1894) was referred as "a highly influential and respected king of the Western rulers (sending and colonial government) because he controlled vast land in Telang and the Lewu Hante complex. He built the building as the centre of Sihong's government in an extensive area". Lewu Hante, a palace and the heart of governance during Ma'anyan Paju Epat era in 1850-1942, was the political identity of the Dayak Ma'anyan tribe. The concept of panatau (wealth) owned by individual leaders and tribal groups in the conception of Dayak Ma'anyan political thought a plays a vital role as a source of power for influencing the others.

\section{Heritage or greatness (symbol of power)}

A symbol of power can take form in a Heritage or greatness. Many villages such as in Paju Epat has their heritage. One widely known heritage from Paju Epat is Sangku Maringkajang which is placed in the middle of the Balai Adat for an important meeting. Another form of heritage was Telang, Heritage or Greatness of Siong, Heritage or Greatness of Murutuwu, Heritage or Greatness of Maipe, and Heritage or Greatness of Balawa. Mangkujati studied the concept of heritage, and he mentioned about Lalayu Lalunsir Bumung Wila Ruji:

\footnotetext{
"Mangku Landui was the last holder of Wilaruji in our family before Wilaruji handed to Datu's brother because Datu had no sons until now. Wilaruji is an object passed down from generation to generation, signifies someone as a leader also as a binder with ancestors, which has existed since the days of Uria Napulangit and Patis Mawuyung from Balawa” (Mangkujati 2003:226).
}

Today, modern elite develop symbols to legitimize the power of their tribes as they construct a government building named Lewu Hante (longhouse), a name refer to the symbol of power in Nan Sarunai era. Elites also build Roundabouts, statues, roads and given the names of past rulers or royal names from the past. In addition, the symbol of power from the past was also implemented into regional district symbols such as the symbol of East Barito and South Barito. Not only reflected on the regional symbol, the but motto of the region was also referred from the past mythology. All symbols implemented in daily life since it signifies 
power, both the power of the family of the tribal leader and the power of the tribe in a whole. In a broader context in the modern world, people implement symbols far beyond barriers on family and group. They built symbols in every city, village and region to show and expose the relation of power to their glory in the past. The symbol of power reflected on their inheritance is another source of power Dayak Ma'anyan political thought.

\section{Influences to the contemporary elites}

Today's elites employ a modern method to exercise political power. Nevertheless, among the Ma'anyan Dayak elite in East Barito, many policies originated from the old (traditional) perspective. Several facts can be identified as influenced by traditional power are: The establishment of East Barito District in 2002 was perceived as a continuation of the Kingdom of Nan Sarunai. The formation of this regency is highly linked to Nan Sarunai, mainly because of its name and territory that written in history as a continuation of a series of Nan Sarunai called Tanah Datar. In the beginning, debates about the naming arose among figures. Some wanted to call it Tanah Datar while others wanted to name it as East Barito. After the area was formed, it was decided that the name was East Barito and they referred it as "Nan Sarunai wau" (new Nan Sarunai), or "Nan Sarunai ngamang talam" (Nan Sarunai a beautiful country). Some others call it as "Nan Sarunai mulek kala mula" (Nan Sarunai when they first started). The myth of Nan Sarunai, along with all aspects of the thought power is powerful influences the political thought and practice of some Dayak Ma'anyan elites in East Barito.

In developing East Barito, the Ma'anyan Dayak elite in government was supported by informal elites to built the symbol of Nan Sarunai's political power reflected on the regional symbol, the Mantawara building, taing name form the name of Balai Adat in Nan Sarunai. The central government offices, such as Chief of Regency office and Regional People's Representative Assembly offices, were built around Mantawara Hall, symbolized three buildings as the centre of the Nan Sarunai government. Names of public facilities such as roads, markets, bridges, buildings, roundabouts, are also taken from the name of the ruler or traditional authority such as Nan Sarunai Street and Tumenggung Jaya Karti market. Lewu Hante (big house) as a traditional symbol of the Dayak Ma'anyan house facilitated by the Regional Government was also built in Telang and Pasar Panas, to show that East Barito Regency as a continuation of the old (traditional) power politics. They also make films, compose songs and sing them which as the symbol of their glory in the past.

The title of a traditional aristocrat or tribal leader that was given to the local political elite was originated from the name of leaders in Nan Sarunai. The use of this title effectively mobilised people in political choices during the elections and made the elite as a patron. Patronage of the local elite seeks representative leaders to carry their voices and interests. They sought and mystified the local elite and title them as of adat leader. They gave the title of Dambung Panning Maleh to the Governor of Central Kalimantan, Teras Narang; and to the East Barito Regent Zain Alkim and Ampera Mebas, hoping that the elite could be a party to bring prosperity. The granting of a traditional title (Galar Mantir) is one source of power in the political thought of the Dayak Ma'anyan tribe which still practised until today.

Other sources of power such as customary law, customs, the concept of Mantir Epat Pangulu Isa's leadership that were practiced villages, symbols of power, the concept of Tutur Mantir, traditional and modern power, rites to respect ancestors and servitude to God is still practiced in the context of implementing old form of powers. Three regents who led East Barito who were elected, Gumarawan Pantie (2002-2003), Zain Alkim (2003-2013), and Ampera Mebas (2013-2018) are descended from Paju Epat. Therefore, tribal political thought as traditional sources of power that had been practised in the past, are still influencing the way of thinking of these tribal elites, especially in exercising power and authority in regency and the village.

\section{Conclusion}

Even though the Dayak Ma'anyan tribe have practised modern politics, political thought about traditional power still profoundly influences the political thinking of the present elites. In political 
thought of Dayak Ma'anyan, power is interpreted as a concept with following characteristics: concrete, whole, real, traditional and charismatic, rooted in social structures that are hierarchically arranged based on lineage and status. Sources of power come from procedural sources (customary law), and substantial sources (God and ancestral spirits, offspring line, material assets and symbols of power). Some of these sources of power still affect the political thought of the Dayak Ma'anyan elite as apparent on the formation of districts, the implementation of politics of identity in bureaucratic policies and the politics of regional head elections, the granting of customary titles to local elites, the implementation of customary law, the implementation of symbols customs such as the regional symbols and regional motto. They also make films, create folk songs and sing them to glorify the power of the past. The circumstances indicate that the influence of traditional power still exists in their current political thinking. The practices of traditional power emerged as the implementation of decentralization, and regional autonomy policies gave freedom to local communities to implement governance based on their customs and culture.

\section{References}

Anderson BRO’G (1984) Gagasan Tentang Kekuasaan Dalam Kebudayaan Jawa. In: M Budiardjo. Aneka Pemikiran Tentang Kuasa dan Wibawa. Jakarta: Penerbit Sinar Harapan.

Andrain CF (1992) Kehidupan Politik dan Perubahan Sosial. Yogyakarta: Tiara Wacana.

Arlius A (2016) Kiaen Wadian Hintek Ijambe (Perjalanan Wadian Saat Upacara Ijambe). Siong: Naskah tidak diterbitkan.

Asmu'ie A (2006) Integrasi Politik di Kalimantan Barat: Studi Kasus di Kabupaten Ketapang. Dissertation, Bidang Studi Ilmu Politik, Program Pascasarjana, FISIP, Universitas Indonesia, Depok.

Bae SU, Bandan DG, \& Martinus (1995) Sejarah Suku Dayak Ma'anyan, Banjar dan Merina di Madagaskar. Hasil Penelitian, Museum Nasional RI. Naskah tidak diterbitkan, Jakarta.

Borneo Institut (2013) Hapakat Manggatang Utus, Dari Kalimantan Tengah Mencari Identitas. Palangka Raya, Borneo Institut.

Budiardjo M (2008) Dasar-Dasar Ilmu Politik. Jakarta: PT. Gramedia.

Carter A (1985) Otoritas dan Demokrasi. Jakarta: Rajawali Pers.

Dubut D (2004) Dayak pasca konflik Sampit: Mendayung di antara dua karang. Jurnal Dayak 21 (I).

Gentong D \& Dusau S (2004) Hukum Adat Dayak Ma'anyan. Buntok: Pemerintah Kabupaten Barito Selatan. Naskah tidak diterbitkan.

Hudson AB (1971) Padju Epat: The Ma'anyan of Indonesia Borneo. New York: Holt, Rinehart, and Winston, Inc.

Mallinckrodt J (1974) Gerakan Nyuli Di Kalangan Suku Dayak Lawangan. Jakarta: Penerbit Bhratara.

Mangkujati A (2003) Wadian Perempuan: Mencari Identitas Dayak Ma'anyan (Masa Kini). In: B Susanto (ed). Politik dan Postkolonialitas di Indonesia. Yogyakarta: Kanisius.

Maunati Y (2005) Identitas Dayak: Komodifikasi dan Politik Kebudayaan. Yogyakarta: LKiS.

Miter HS (2015) Amirue dan Roh Kudus: Sejarah Perjumpaan Ulun Ma'anyan dengan Kekristenan. Sendawar, Kutai Barat: YRSKLR dan Araska Publisher.

Miter HS (2017) Suta Ono: Kepemimpinan Kharismatik Seorang Kepala Suku Dayak Ma'anyan Paju Epat. Thesis, Sekolah Tinggi Teologi Gereja Kalimantan Evangelis, Banjarmasin.

Ngepek A (2008) Sejarah Singkat Kabupaten Barito Timur. Naskah Pidato, dibacakan setiap HUT Kabupaten Barito Timur pada tanggal 3 Agustus. Naskah tidak diterbitkan.

Noer D (1983) Pengantar ke Pemikiran Politik. Jakarta: CV. Rajawali.

Sorosilah Nan Sarunai (n.d.) Naskah tidak diterbitkan. 
Surbakti R (1992) Memahami Ilmu Politik. Jakarta: Gramedia.

Suryadinata L, Arifin EN, \& Ananta A (2003) Penduduk Indonesia: Etnis dan Agama dalam Era Perubahan Politik. Jakarta: LP3ES.

Somantri GR (2005) Memahami metode kualitatif.Jurnal Sosial Humaniora "Makara"IX (2).

Suseno FM (2003) Etika Politik: Prinsip-Prinsip Moral Dasar Kenegaraan Modern. Jakarta: PT. Gramedia.

Taliwakas Ma'anyan (n.d.) Naskah tidak diterbitkan.

Tulus P., Rama (2010) Agama Sebagai Identitas Sosial: Studi Sosiologi Agama Terhadap Komunitas Ma'anyan. Dissertation, Kajian Sosiologi Agama, Program Pascasarjana Sosiologi Agama Universitas Kristen Satya Wacana, Salatiga.

van Klinken G (2010) Kembalinya Para Sultan: Pentas Gerakan Komunitarian Dalam Politik Lokal. In: JS Davidson, et al. (eds). Adat Dalam Politik Indonesia. Jakarta: Buku Obor dan KITLVJakarta.

Wada M (2003) Adat, Hukum Adat dan Budaya Dayak Ma'anyan Paju Sapuluh. Tamiang Layang, Naskah tidak diterbitkan.

Ugang H (1987) Belanga-Belanga Keramat: Sebuah Penilaian Antropologis-Teologis tentang Pandangan orang Dayak Kalimantan Tengah mengenai Harta Kekayaan Material. Dissertation, Sekolah Tinggi Teologi Jakarta, Jakarta.

Ukur F (1971) Tantang-Djawab Suku Dajak. Dissertation, Sekolah Tinggi Teologia Jakarta, Jakarta.

Ukur F (1974) Ijambe, Upacara Pembakaran Tulang di Kalangan Suku Dayak Ma'anyan di Kalimantan Tengah. In: Majalah Paninjau, Lembaga Penelitian dan Studi Dewan Gerejagereja di Indonesia (DGI) I.

Ukur F (1992) Kebudayaan Dayak. In: Majalah Kalimantan Review No. 02 Tahun I, Juli-Desember 1992. 